Vol. 4 No.1 Februari 2022

\title{
PENERAPAN PEMULIHAN TRANSFORMATIF DIGITALISASI UMKM DI KOTA PADANG
}

\author{
DABITHA WISE MALIHA \\ STIA Adabiah \\ dabithawisemaliha@gmail.com
}

\begin{abstract}
This article aims to elaborate on transformative recovery efforts digitization of SME's in Padang city. The Covid-19 pandemic gives drastically impact on SME's income. However, along gradually economic recovery, Padang City Government have been striving for transformative recovery through several programs to support SME's digitalization ecosystem. This article uses a literature study method by analyze information from various literatures. The results show Padang City Government has implemented several programs in form of mentoring, training and socialization for SME's actors that related on strategic steps prepared by The Ministry of Cooperatives and SME's for realization of digital entrepreneurship ecosystem.
\end{abstract}

Keywords: SME's, Digital Entrepreneurship, Covid-19

\begin{abstract}
Abstrak: Artikel ini bertujuan mengelaborasi upaya pemulihan transformatif digitalisasi UMKM di Kota Padang. Pandemi Covid-19 memberikan dampak penurunan drastis pendapatan bagi pelaku UMKM. Namun seiring berangsurnya pemulihan ekonomi, Pemerintah Kota Padang mengupayakan pemulihan transformatif melalui beberapa program untuk mendukung ekosistem digitalisasi bagi UMKM. Artikel ini menggunakan metode studi kepustakaan dengan menganalisis informasi dari berbagai literatur. Hasil analisa menunjukkan bahwa Pemerintah Kota Padang telah melaksanakan beberapa program berupa pendampingan, pelatihan dan sosialisasi bagi pelaku UMKM yang berhubungan dengan langkah strategis yang telah disiapkan oleh Kementerian Koperasi dan UKM demi terwujudnya ekosistem kewirausahaan digital.
\end{abstract}

Kata Kunci: UMKM, Kewirausahaan Digital, Covid-19

\section{A. Pendahuluan}

Pandemi Covid-19 memberikan dampak besar terpuruknya sektor penggerak ekonomi terutama sektor UMKM (Usaha Mikro Kecil Menengah). Sebagaimana Bank Indonesia menyebutkan sebanyak 87,5 persen UMKM di Indonesia merasakan dampak negatif dari Covid-19. Adapun dari jumlah ini, sekitar 93,2 persen terdampak menurunnya omset di sisi penjualan (bisnis.com, 2021). Padahal UMKM merupakan pilar terpenting bagi perekonomian di Indonesia. Hal ini terbukti dari data Kementerian Koperasi dan Usaha Kecil Menengah (KemenkopUKM) di bulan Maret 2021, jumlah UMKM mencapai 64,2 juta dengan kontribusinya terhadap Produk Domestik Bruto (PDB) sebesar 61,07 persen atau senilai Rp $8.573,89$ triliun. Selain itu, UMKM mampu menyerap 97 persen dari total tenaga kerja sehingga dapat menghimpun 60,42 persen dari total investasi di Indonesia (kemenkeu.go.id, 2021).

Oleh karena akibat penurunan drastis dari segi pendapatan akibat pandemi Covid-19, UMKM mengalami resiko bangkrut dan pekerjanya terpaksa di berhentikan sehingga hal ini dapat mempengaruhi pertambahan angka pengangguran di Indonesia. Padahal dari pengalaman krisis ekonomi sebelumnya, UMKM mampu menjaga ketahanannya. Sebagaimana kajian Lembaga Pengembangan Perbankan Indonesia dan Bank Indonesia menyebutkan bahwa jumlah UMKM pasca krisis ekonomi tahun 1997-1998 justru meningkat, bahkan menyerap 85 juta hingga 107 juta tenaga kerja hingga tahun 2012. Dan di tahun 2012, sebanyak 99,99 persen pengusaha di Indonesia adalah pelaku UMKM (tirto.id, 2021)

Namun seiring menurunnya kasus Covid-19 di Indonesia, Menteri Koperasi dan UMKM Teten Masduki mengatakan, kondisi UMKM di kuartal II 2021 mulai kembali normal. 
Sebagaimana berdasarkan hasil survey Mandiri Institute pada 2021, sebanyak 85 persen responden menyebutkan kondisi usahanya mulai berjalan normal pada kuartal kedua (kompas.com, 2021). Selain itu, seiring memasuki era new normal, jumlah pelaku UMKM yang harus menutup usahanya untuk tutup sementara telah berkurang. Hal ini terbukti dari survey Asian Development Bank terhadap 2.509 UMKM secara nasional telah memulai kembali membuka usahanya. Ekonom Senior ADB Shigehiro Shinozaki mengatakan bahwa adanya usaha yang sudah mulai buka kembali menandakan bahwa Indonesia telah pindah ke tahap pemulihan ekonomi (tirto.id, 2021).

Seiring berangsurnya pemulihan ekonomi, Kementerian Koperasi dan UMKM menerapkan lima fondasi ekosistem usaha adaptif yang telah disiapkan sepanjang tahun 2021. Adapun kelima fondasi tersebut yaitu: kemudahan akses pembiayaan, perluasan pasar dan digitalisasi, kemitraan, pendataan dan birokrasi. Pertama, fondasi kemudahan akses pembiayaan berupa pemberian hibah (BPUM) kepada 12,8 juta pelaku UMKM sebesar Rp 15,36 triliun. Selain itu, pelaku UMKM juga diberikan tambahan subsidi bunga KUR 3\% dengan target disalurkan kepada debitur sebanyak Rp 285 triliun. Kedua, fondasi perluasan pasar dan digitalisasi yang dalam kurun satu tahun, onboarding UMKM meningkat dari sebelumnya 8 juta di awal tahun 2020 menjadi 16,9 juta pada November 2021. Ketiga, fondasi kemitraan yang mana telah di dilaksanakan kemitraan dengan 9 perusahaan seperti: PT Mitra Bumdes Nusantara, Microsave Consulting, Uniqlo, IKEA, Tokopedia, MNC Group, Ina Product, Grab dan Gojek. Keempat, fondasi pendataan yang disinergikan ke dalam NIB, BPUM, KUR dan Koperasi. Terakhir, fondasi reformasi birokrasi melalui penyederhanaan kelembagaan Kementerian Koperasi dan UMKM dari 6 kedeputian menjadi 4 kedeputian (kemenkopukm.go.id, 2021).

Memasuki tahun 2022, pemerintah optimis UMKM mampu bangkit dan kembali pulih seperti sebelum masa pandemi. Menteri Teten mengatakan bahwa menuju tahun 2022, koperasi dan UMKM memasuki fase pemulihan transformatif, yaitu tahap kebangkitan koperasi dan UMKM bermodalkan lima fondasi adaptasi yang telah disiapkan sepanjang 2021. Saat ini, pemerintah telah menyiapkan tiga agenda dan diharapkan pemulihan ini tidak hanya menyiapkan UMKM tumbuh seperti sebelum pandemi, melainkan lebih siap menghadapi krisis di masa yang akan datang. Transformasi pertama, program KemenkopUKM menyasar pelaku anak muda, perempuan dan dukungan pada usaha ramah lingkungan. Transformasi kedua, mendorong pembiayaan bergeser dari sektor perdagangan ke sektor riil. Transformasi ketiga, menargetkan minimal 20 juta UMKM masuk ke dalam ekosistem digital (kemenkopukm.go.id, 2021).

Pemerintah menargetkan pemulihan transformatif ini juga dapat terealisasikan ke seluruh daerah di Indonesia. Sehingga pemerintah di daerah seperti Pemerintah Kota Padang turut mengupayakan program dari ketiga agenda tersebut. Mengingat di masa pandemi, pelaku UMKM di Kota Padang juga turut merasakan dampak negatif dan mengalami berbagai kesulitan seperti menurunnya penjualan, kesulitan bahan baku dan permodalan sehingga menghambat aktivitas produksi. Sebagaimana data yang dihimpun oleh Dinas Koperasi dan UMKM Kota Padang, jumlah UMKM yang terdampak mencapai 10.468 unit yang berasal dari 11 kecamatan dan 104 kelurahan di Kota Padang (Padek, 2020). Akibat permasalahan tersebut, Dinas Koperasi dan UMKM Kota Padang mengupayakan pemulihan transformatif ini agar pelaku UMKM mampu bertahan meski masih dalam kondisi krisis.

Mengingat survey BI mencatat terdapat 12,5\% UMKM yang mampu beradaptasi di masa pandemi (katadata.co.id, 2021). Artikel ini lebih berfokus mengelaborasi pengembangan upaya pemulihan transformatif pada transformasi ketiga yaitu kewirausahaan digital UMKM di Kota Padang. Oleh karena kewirausahaan digital merupakan salah satu solusi bagi UMKM di Kota Padang untuk mampu bertahan di masa pandemi. Sehingga, hal ini mengajak pertanyaan; Bagaimana upaya pemerintah Kota Padang dalam mengupayakan pemulihan transformatif melalui digitalisasi UMKM? Adapun tujuan dari artikel ini untuk menganalisis hal yang telah diupayakan dalam merealisasikan pemulihan transformatif digitalisasi UMKM 
di Kota Padang. Batasan dari artikel ini hanya seputar implikasi deskriptif pada upaya pengembangan digitalisasi UMKM.

Kewirausahaan melibatkan bagaimana pelaku usaha mengenal dan merebut peluang, mentransformasikan peluang tersebut menjadi barang dan jasa yang dapat dipasarkan dengan mengasumsikan resiko, sehingga penciptaan nilai baru merupakan karakteristik dari kewirausahaan. (Hull et al., 2007). Sedangkan kewirausahaan digital didefenisikan sebagai mencapai peluang bisnis dan ekonomi berdasarkan penggunaan teknologi digital (Davidson \& Vaast, 2010). Wirausaha digital merupakan fenomena munculnya perkembangan teknologi informasi dan komunikasi yang mana penjualan produk dan jasa dilakukan melalui jejaring elektronik (Guthrie, 2014). Wirausaha digital juga merupakan subkategori dari kewirausahaan yang mana beberapa bahkan keseluruhan fisikal dari organisasi tradisional didigitalisasikan (Hull et al., 2007).

Hull et al (2007) mengkategorikan kewirausahaan digital menjadi tiga tipe. Pertama kewirausahaan digital ringan, melibatkan usaha ke digital ekonomi sebagai suplemen untuk lebih ke usaha tradisional. Kedua, kewirausahaan digital menengah, memerlukan fokus yang signifikan pada produk digital, pengantaran digital, atau komponen bisnis digital lainnya. Hal ini tidak terwujud tanpa infrastruktur digital. Ketiga, kewirausahaan digital ekstrim, merupakan usaha yang sepenuhnya telah digital, termasuk memproduksi barang atau jasa sendiri, iklan, distribusi dan pelanggan. Bahkan menjual produk dan jasa digital dilakukan dengan transaksi mata uang digital.

\section{B. Metodologi Penelitian}

Artikel ini menggunakan studi kepustakaan yang menggunakan pengumpulan informasi dan data dari berbagai literatur seperti buku, jurnal dan data referensi relevan lainnya untuk mendapatkan jawaban dan landasan teori mengenai masalah yang diteliti (Indrawan \& Yaniawati, 2014). Adapun ciri metode studi kepustakaan yakni; Pertama, penulis mendapatkan data berupa teks maupun angka dari berbagai sumber referensi literatur yang relevan, bukan dari pengetahuan langsung dari lapangan. Kedua, data pustaka bersifat siap pakai dan bersifat valid. Ketiga, data pustaka umumnya adalah sumber sekunder, sehingga penulis memperoleh data dari tangan kedua dan bukan data orisinil dari data pertama di lapangan. Keempat, bahwa kondisi data pustaka tidak dibatasi oleh ruang dan waktu (Zed, 2003). Adapun langkah kegiatan yang telah dilaksanakan oleh penulis yakni; Pertama, penulis mengamati fenomena yang berkaitan dengan topik artikel. Kedua, penulis menentukan fokus penelitian dari informasi yang didapatkan dari berbagai literatur yang terkait. Ketiga, penulis menganalisis data yang diperoleh dan menelaahnya sehingga menjadi ide baru yang terkait dengan topik artikel. Terakhir, penulis menganalisis catatan dari berbagai literatur sehingga dapat menarik kesimpulan yang disusun dalam bentuk laporan penelitian.

\section{Hasil dan Pembahasan}

Pengupayakan pemulihan transformatif digitalisasi, Kemenkop UKM memiliki empat langkah strategi. Pertama, meningkatkan Sumber Daya Manusia (SDM) dengan mempersiapkan kapasitas pelaku UMKM meningkat. Kedua, mengintervensi perbaikan proses bisnis UMKM yang diturunkan ke dalam beberapa program. Ketiga, perluasan akses pasar dengan bekerja sama dengan Lembaga Kebijakan Pengadaan Barang/Jasa Pemerintah (LKPP) agar pelaku UMKM bisa menjadi vendor pengadaan barang dan jasa pemerintah. Keempat, glorifikasi pahlawan lokal pelaku UMKM (kemenkopUKM.go.id, 2020). Adapun keempat langkah ini menjadi pembahasan artikel ini yang berfokus di Kota Padang.

\section{Meningkatkan Sumber Daya Manusia}

Upaya meningkatkan SDM pelaku UMKM di Kota Padang, Pemerintah Kota (Pemko) Padang telah menyiapkan berbagai proses pendampingan yang meliputi sosialisasi, pelatihan, evaluasi dan monitoring. Menurut Najiyati et al (2005) dalam Mulyadi et al (2019) tahapan 
pendampingan terdiri dari tahap persiapan, kapasitasi, dan terminasi: a) Tahap Persiapan. Pemko Padang mengumpulkan pelaku UMKM kemudian memperkenalkan diri, lembaga, maksud dan tujuan dari kegiatan yang akan dilaksanakan. Tahap ini disebut juga masa sosialisasi, sehingga kegiatan ini bisa melibatkan lembaga lain atau organisasi masyarakat dalam mensosialisasikan pendampingan bagi pelaku UMKM; b) Tahap Kapasitasi, Pemko Padang memberikan kesempatan pelaku UMKM untuk membangun kemampuan mereka sendiri. Di tahap ini dilaksanakan berbagai pelatihan seperti perencanaan bisnis, pemasaran, kelola keuangan dan pelatihan lainnya untuk meningkatkan kompetensi SDM bagi pelaku UMKM, c) Tahap Terminasi, pelaku UMKM sudah mencapai tahap mandiri sehingga proses pendampingan harus diakhiri. Kemandirian dapat dilihat dari profesionalisme pelaku UMKM dalam menjalankan sistem manajemen usahanya.

Sebagai kota yang mengandalkan wisata kulinernya, Pemko Padang melalui Dinas Koperasi dan UKM Kota Padang telah melaksanakan beberapa program pendampingan untuk meningkatkan kualitas SDM bagi pelaku UMKM. Seperti menggelar pelatihan inkubasi kuliner di Royal Asia College, Jalan Samudera Pantai Padang. Pelatihan ini dilaksanakan selama lima hari sejak tanggal 8 sampai dengan 12 November 2021 yang diikuti oleh 26 orang peserta berasal dari Kecamatan Padang Utara (harianhaluan.com, 2021). Pelatihan ini menghadirkan chef terkenal dengan diberikan keilmuan 3 menu makanan per harinya. Adapun tujuan pelatihan ini diharapkan dapat menambah wawasan, keterampilan dan kapasitas pelaku UMKM di bidang kuliner agar lebih inovatif dan kreatif.

Selain menambah kapasitas hard skill bagi pelaku UMKM, Pemko Padang juga berupaya meningkatkan kompetensi soft skill dengan melaksanakan pelatihan digitalisasi UMKM. Mengingat semakin meningkatnya pasar dunia virtual, Pemko Padang mengadakan pelatihan Digital Entrepreneurship Academy (DEA) melalui Dinas Komunikasi dan Informatika Kota Padang dan Dinas Perindustrian dan Perdagangan Koperasi UKM Kota Padang dengan menjalin kerjasama dengan Balai Besar Pengembangan Sumber Daya Manusia dan Penelitian Komunikasi dan Informatika (BBPSDMP Kominfo) Medan. Pelatihan ini digelar selama dua hari pada tanggal 23-24 Juni di Hotel IBIS Kota Padang dengan jumlah peserta sebanyak 70 pelaku UMKM (bbpsdmp.medan, 2021). Pada pelatihan ini, para peserta dilatih untuk mampu memanfaatkan platform digital sehingga dapat memaksimalkan pemasaran produk secara luas.

\section{Intervensi Proses Bisnis}

Untuk mengupayakan kemudahan proses bisnis berwirausaha bagi UMKM, pemerintah memberikan penyederhanaan prosedur perijinan melalui One Single Submission (OSS). Kemudian, pemerintah juga memberikan keringanan biaya perijinan bagi UMKM serta dukungan pembiayaan yang terjangkau. Saat UMKM terbentuk, pemerintah juga memberi penyederhanaan administrasi perpajakan, insentif pajak dan kepabeanan. Dalam fase pengembangan, pendampingan juga diberikan agar pelaku UMKM mampu mengakses pembiayaan serta menguatkan kapasitas pelaku usaha pemula (kemenkeu.go.id, 2020).

Untuk memaksimalkan program kemudahan proses bisnis ini, Pemko Padang melalui Dinas Penanaman Modal dan Pelayanan Terpadu Satu Pintu (DPMPTSP) Kota Padang menggelar temu usaha dan kemitraan dengan pelaku usaha di Hotel Pangeran Beach pada tanggal 17 November 2021. Kegiatan ini mengangkat tema "Temu Usaha dan Kemitraan dengan Pelaku Usaha untuk mewujudkan Ekosistem Investasi dan Kemudahaan Berusaha di Kota Padang." Adapun tujuan dari kegiatan ini untuk memberikan informasi kepada pelaku usaha tentang regulasi penanaman modal, kemudahan berusaha, kenyamanan dan kepastian hukum dalam berinvestasi (padang.go.id, 2021).

Selain itu, temu usaha ini juga memberikan informasi sistem digital dalam hal pemenuhan komitmen administrasi dan pendataan melalui penggunaan aplikasi terbaru dalam berinvestasi yakni Online Single Submission Risk Based Approach (OSS-RBA). Dengan adanya program ini, diharapkan Kota Padang menjadi kota yang diminati oleh investor baik dalam negeri maupun luar negeri sehingga mampu memaksimalkan potensi UMKM untuk 
terus mengembangkan bisnisnya. Sehingga regulasi perda diharapkan mampu meningkatkan ekosistem investasi dan kemudahan berusaha yang semakin baik.

\section{Perluasan Akses Pasar Pengadaan Barang dan Jasa}

Terkait dengan adanya Perpres Nomor 12 Tahun 2021, Pemko Padang melalui Bagian Pengadaan Barang/Jasa (BPBJ) mengadakan kegiatan sosialisasi berhubungan dengan adanya kesempatan bagi pelaku UMKM untuk menjadi peserta lelang pengadaan barang dan jasa (PJB). Kegiatan ini berlangsung selama 2 hari pada tanggal 16-17 Maret 2021 di Hotel Rocky Plaza. Sebagaimana dalam Perpres No. 12 Tahun 2021 ini, pemerintah melakukan perubahan nilai paket untuk usaha kecil sehingga dapat memberikan kesempatan lebih luas kepada UMKM. Diharapkan dengan diberlakukan peraturan ini dapat memberikan pemenuhan nilai manfaat sebesar-besarnya (value for money) dan peningkatan peran bagi UMKM dan kapasitas produk dalam negeri (kabarsumbar, 2021).

Pelaku UMKM yang mengikuti lelang Pengadaan Barang dan Jasa (PJB) dapat bergabung di 12 marketplace yang telah bekerja sama dengan Lembaga Kebijakan Pengadaan Barang dan Jasa Pemerintah (LKPP) dengan mendaftar online di kanal Sistem Informasi Kinerja Penyedia (SIKap) (cnbcindonesia.com, 2021). Dengan kemudahan akses pelaku UMKM untuk dapat mengikuti lelang PJB melalui marketplace, pelaku UMKM diharapkan mampu bersaing di dunia digital dan mempermudah akses pasarnya menjadi vendor pengadaan barang dan jasa pemerintah.

\section{Glorifikasi Pahlawan Digital}

Kemenkop UKM saat ini telah meluncurkan program "Pahlawan Digital UMKM" yang ditujukan untuk memanfaatkan teknologi digital dalam pengembangan UMKM. Adapun target peluncuran program ini bertajuk "Inovasi untuk UMKM Go Digital" diselenggarakan dalam rangka memberikan apresiasi kepada para innovator digital UMKM. Bertepatan di Hari Sumpah Pemuda, program ini telah mengumumkan 10 inovator muda yang telah memberikan solusi digital bagi UMKM (news.detik.com, 2020). Adapun dengan adanya finalis diharapkan dapat menjadi role model bagi pelaku UMKM di Indonesia.

Mengingat program ini dilaksanakan secara nasional, program ini juga dapat memberikan inspirasi bagi Pemko Padang untuk memberikan penghargaan kepada anak muda pelaku UMKM untuk mampu mengembangkan bisnis go digital. Seperti mengadakan kerja sama dengan Perguruan Tinggi untuk mengadakan kompetisi bagi mahasiswa yang memiliki ide kreatif untuk mengembangkan usaha digital bagi UMKM. Selain itu, Pemko Padang juga dapat menunjuk duta digital UMKM sebagai role model bagi anak muda untuk berwirausaha secara digital.

\section{Penutup}

Pandemi Covid-19 memberikan banyak dampak negatif terhadap kestabilan ekonomi terutama pada UMKM. Namun, pandemi Covid-19 juga dapat mendorong terciptanya ekosistem kewirausahaan digital sehingga dapat mendorong program digitalisasi UMKM di Kota Padang. Adapun Pemerintah Kota Padang juga telah mendukung upaya pengembangan UMKM digital dengan mengikuti beberapa langkah strategis dari Kementerian Koperasi dan UKM, yakni; (1) melaksanakan program pendampingan di bidang kuliner dan digitalisasi, (2) sosialisasi temu usaha untuk mewujudkan ekosistem investasi dan kemudahan berusaha, (3) memberikan kesempatan pelaku UMKM menjadi peserta lelang Pengadaan Barang dan Jasa. Namun, program tersebut tidak cukup tanpa adanya sinergitas antara pemerintah, pelaku UMKM dan pemangku kepentingan lainnya. Sehingga untuk membentuk ekosistem kewirausahaan digital dibutuhkan keterlibatan banyak pihak yang berperan kontributif dalam mewujudkan pemulihan transformatif digitalisasi di Kota Padang. 


\section{Daftar Pustaka}

BBPSDMP Medan. (2021). Pelatihan Digital Entrepreneurship Academy (DEA) di Kota Padang. Diakses pada 23 Juni 2021, dari https://bbpsdmpmedan.kominfo.go.id/pelatihan-digital-entrepreneurship-academy-dea-di-kota-padang/

Davidson, E., Vaast, E. (2010). Digital entrepreneurship and its socio-material enactment. In: 43rd Hawaii International Conference on System Sciences (HICSS), pp. 1-10. IEEE (2010)

Detiknews. (2020). Inilah Para Pahlawan Digital. Diakses pada 29 Oktober 2020, dari https://news.detik.com/berita/d-5234157/inilah-para-pahlawan-digital-umkm-2020

Guthrie, C. (2014). The digital factory: a hands-on learning projectdigital entrepreneurship. Journal of Entrepreneurship Education. Vol. 17 No. 1

Harianhaluan.com. (2021). Tingkatkan SDM Pelaku Usaha Mikro, Pemko Padang Gelar Pelatihan Kuliner. Diakses pada 12 November 2021, dari https://www.harianhaluan.com/news/pr-101631547/tingkatkan-sdm-pelaku-usahamikro-pemko-padang-gelar-pelatihan-kuliner

Hastuti, Rahajeng Kusumo. (2021, 14 Oktober). UMKM Punya Peluang Ikut Pengadaan Barang Jasa Pemerintah. CNBC Indonesia. Diakses dari

https://www.cnbcindonesia.com/news/20211014194846-4-284016/umkm-punya-peluang-ikutpengadaan-barang-jasa-pemerintah

Hull, C.E., Hung, Y.-T.C., Hair, N., Perotti, V. and DeMartino, R. (2007). Taking advantage of digital opportunities: a typology of digital entrepreneurship. International Journal of Networking and Virtual Organizations, Vol. 4 No. 3, pp. 290-303.

Indrawan, R., \& Yaniawati, P. (2014). Metodologi penelitian kuantitatif, kualitatif, dan campuran untuk manajemen, pembangunan, dan pendidikan. Bandung: PT. Refika Aditama.

Iswara, Made Anthony (2021, 10 September). Menilik Harapan UMKM untuk Bangkit dari Pandemi Covid-19. Tirto.id. Diakses dari https://tirto.id/menilik-harapan-umkm-untukbangkit-dari-pandemi-covid-19-gjj4

Kementerian Keuangan. (2021). Pemerintah Terus Perkuat UMKM Melalui Berbagai Bentuk Bantuan. Diakses pada 27 September 2021, dari

https://www.kemenkeu.go.id/publikasi/berita/pemerintah-terus-perkuat-umkm-melaluiberbagai-bentuk-bantuan/

Kementerian Keuangan. (2020). Ini Sederet Upaya Pemerintah Memajukan UMKM. Diakses pada 15 Oktober 2020, dari https://www.kemenkeu.go.id/publikasi/berita/ini-sederetupaya-pemerintah-memajukan-umkm/

Kementerian Koperasi dan UKM. (2021). Menteri Teten: Fondasi Telah Kuat, Tahun 2022 Masuk Fase Pemulihan Transformatif. Diakses pada 30 Desember 2021, dari https://kemenkopukm.go.id/read/menteri-teten-fondasi-telah-kuat-tahun-2022-masukfase-pemulihan-transformatif

Kementerian Koperasi dan UKM. (2020). Empat Langkah Transformasi Digital Pelaku UMKM. Diakses pada 11 November 2020, dari https://kemenkopukm.go.id/read/empatlangkah-transformasi-digital-pelaku-umkm

Mulyadi., Wahyuni, S., dan Tanjung, H.B. (2019). Proses Pendampingan Oleh Pemangku Kepentingan dalam Pengembangan Sumber Daya Manusia Pelaku Industri Kuliner Rendang di Kota Padang. Jurnal Niara Vol. 12, No. 1 Juni 2019, Hal. 100-108.

Padang.go.id. (2021). DPMPTSP Padang Gelar Temu Usaha dengan Pelaku UMKM. Diakses pada 18 November 2021, dari https://www.padang.go.id/dpmptsp-padang-gelar-temuusaha-dengan-pelaku-umkm

Padek. (2020). 10.468 UMKM Terdampak Covid-19 Pemerintah Harus Berikan Stimulus. $\begin{array}{lllll}\text { Diakses } & \text { pada } & 8 & \text { April } & 2020,\end{array}$ https://padek.jawapos.com/sumbar/padang/08/04/2020/10-468-umkm-terdampak-covid19-pemerintah-harus-berikan-stimulus/ 
Saputra, Dany. (2021, 19 Maret). Survei BI : 87,5 Persen UMKM Indonesia Terdampak Pandemi Covid-19. Bisnis.com. Diakses dari

https://ekonomi.bisnis.com/read/20210319/9/1370022/survei-bi-875-persen-umkm-indonesiaterdampak-pandemi-covid-19.

Ulya, Fika Nurul. (2021, 5 Agustus). Menkop Teten: Kondisi UMKM Mulai Pulih di Kuartal II 2021. Kompas.com. Diakses dari

https://money.kompas.com/read/2021/08/05/162817326/menkop-teten-kondisi-umkm-mulaipulih-di-kuartal-ii-2021

Wahyuni, Diah Sri. (2021, 16 Maret). Pemko Padang Adakan Sosialisasi Terkait Pengadaan Barang. Kabarsumbar.com. Diakses dari www.kabarsumbar.com/berita/pemko-padangadakan-sosialisasi-terkait-pengadaan-barang/

Zed, Mestika. (2003). Metode Penelitian Kepustakaan. Jakarta : Yayasan Obor Indonesia 